\title{
Synovial Biopsy
}

National Cancer Institute

\section{Source}

National Cancer Institute. Synovial Biopsy. NCI Thesaurus. Code C51731.

Removal of synovial tissue for microscopic examination. 